sontain a detailed analysis of all the "Opinions" ;o far rendered by the International Commission $n$ regard to the interpretation of the provisions of the Code. "The Official List of Generic Names n Zoology" was established by the International Jongress of Zoology at its meeting at Monaco n 1913 for the purpose of recording full particulars selating to the names of the 5,000-10,000 best-known and most important genera in the animal kingdom with their type species. So far, however, only about seven hundred names have been placed on the "Official List", due largely to the fact that the decisions taken by the International Commission have never hitherto been brought together in a single volume and with a full index. It is hoped that the "Official List" will now develop into a powerful instrument for stabilizing zoological nomenclature. It is hoped that its publication in book form will stimulate specialists to make proposals for the addition of other generic names important not only in systematic zoology but also in the applied sciences and in the teaching of zoology at the universities.

The International Commission is anxious to issue each of the above works at the lowest possible price. for it desires that both shall be within the financial means of every zoologist. This will only be possible if, before publication, the Commission is assured of a sufficient volume of immediate sales. Zoologists are accordingly invited at once to register themselves as prospective subscribers. As soon as the publication price has been fixed, a notification will be sent to all such subscribers, who will be granted a discount of 20 per cent on the publication price, provided that payment at the reduced rate is made to the Commission before the date of publication. All inquiries should be addressed to the International Commission on Zoological Nomenclature at its Publications Office, 41 Queen's Gate, London, S.W.7.

\section{Globe Lightning}

WHAT appears to have been a clear example of globe lightning has been described by Mr. B. E. Waye, "Larch Gates", Altwood Bailey, Maidenhead, Berks. He writes, "At about 2.20 a.m. on May 8, during the height of an intense thunderstorm, I observed a roughly circular orange glow, about the same apparent diameter as the sun, on the horizon, in a southerly direction. The glow was moving towards the west and was followed by a horizontal column of white vapour. It took about ten seconds to reach a point in the south-west, when it disappeared with a flash the succeeding noise could not be distinguished with certainty from other claps of thunder."

\section{Lady Tata Memorial Trust}

The trustees of the Lady Tata Memorial Fund announce that, on the recommendation of their Scientific Advisory Committee, they have made the following awards for research in blood diseases, with special reference to leukæmia, for the academic year beginning on October 1, 1945. Grants for research expenses: Dr. P. A. Gorer (London) and Dr. A. H. T. Robb-Smith (Oxford). Personal grant: Dr. Penelope K. Hammick (Oxford). Part-time personal grant and grant for research expenses : Dr. W. Jacobson (Cambridge). Since these awards do not fully use the margin of funds available, it is hoped to issue a public advertisement for new candidates from the continent of Europe and elsewhere, as soon as conditions permit.

\section{Summer Schools in Health Education}

The Central Council for Health Education will conduct two summer schools in England this year. One will be residential, during August 4-13, at Kingsmoor School, Glossop, Derbyshire; the other will be non-residential, during August 15-29, at Chelsea Polytechnic, Manresa Road, Chelsea, London, S.W.3. The Glossop school will be directed by Mrs. F. A. Ogden, and the London school by Mr. L. J. F. Brimble. The schools are intended primarily for those who have to do with the training and care of children and young people-teachers, youth leaders, health visitors, school nurses, educational and medical administrators-but would also be of interest to general practitioners. The object of the schools is to review the principles of mental and physical health and development, to discuss the main health problems confronting the individual and the community, and to consider the methods of health education, including sex education. Those wishing to book accommodation or to be supplied with further details about the schools should write to the Medical Adviser and Secretary, Central Council for Health Education, Tavistock House, Tavistock Square, London, W.C.l. The Scottish Council for Health Education is holding a residential summer school at the University of St. Andrews during August 18-September 1. The directors of the school are Prof. Andrew F. Skinner, of the University of St. Andrews, and Prof. A. D. Peacock, of University College, Dundee. Courses and lectures will be given under the headings of physiology, psychology and social medicine. Further information concerning the Scottish school can be obtained from the Secretary and Treasurer, Scottish Council for Health Education, 3 Castle Street, Edinburgh, 2.

\section{Announcements}

UNDER the statute of the Royal Society which provides for the election of persons who either have rendered conspicuous service to the cause of science or are such that their election would be of signal benefit to the Society, the Right Hon. Sir John Anderson, Chancellor of the Exchequer, has been elected a fellow of the Society.

DuRING his recent tour in Sweden to lecture on penicillin, under the auspices of the British Council and at the invitation of the Swedish Medical Society, Sir Howard Florey, professor of pathology in the University of Oxford, was presented with the Berzelius Medal in silver. This Medal was given to members of the Swedish royal family and certain other distinguished persons when it was instituted in 1850 but has not been awarded since that time.

Sir D'ARCy Thompson, professor of natural history in the University of St. Andrews, has been awarded the Daniel Giraud Elliot Medal for 1942 by the U.S. National Academy of Sciences. The Medal is awarded for distinguished work in some branch of zoology or palæontology.

A CONFEREnCE on "School and Society" will be held under the auspices of the Institute of Sociology at St. Hilda's College, Oxford, during July 26August 3. The president of the conference will be Sir David Ross, whose presidential address is "The Challenge: the Present Crisis and the Needed Revolution". Further information concerning the conference can be obtained from the Hon. Organizer, Institute of Sociology, Le Play House, Albert Road South. Great Malvern. Worcestershire. 